\title{
Lack of Association of Coffee Consumption with the Prevalence of Self-Reported Type 2 Diabetes Mellitus in a Mexican Population: A Cross-Sectional Study
}

\author{
Ana Karen Gil-Madrigal ${ }^{1}$, Thelma Beatriz González-Castro ${ }^{2}$ (D), \\ Carlos Alfonso Tovilla-Zárate 1,*(D), Daniela Georgina Aguilar-Velázquez ${ }^{1}$, \\ Tania Guadalupe Gómez-Peralta ${ }^{1}$, Isela Esther Juárez-Rojop ${ }^{3, *}$, María Lilia López-Narváez ${ }^{4}$, \\ Elizabeth Carmona-Díaz ${ }^{1}$, Ana Fresan ${ }^{5} \mathbb{D}^{\mathbb{D}}$, Jorge Luis Ble-Castillo ${ }^{3}$, \\ Antonia Pérez-Mandujano ${ }^{3}$ and Crystell Guzman-Priego ${ }^{3}$ \\ 1 División Académica Multidisciplinaria de Comalcalco, Universidad Juárez Autónoma de Tabasco, \\ Comalcalco 86650, Tabasco, Mexico, karen_gmadrigal@hotmail.com (A.K.G.-M.); \\ daniela-azul@hotmail.com (D.G.A.-V.); tanyperalta93@gmail.com (T.G.G.-P.); \\ elizadiaz1@hotmail.com (E.C.-D.) \\ 2 División Académica Multidisciplinaria de Jalpa de Méndez, Universidad Juárez Autónoma de Tabasco, \\ Jalpa de Méndez 86205, Tabasco, Mexico; thelma.glez.castro@gmail.com \\ 3 División Académica de Ciencias de la Salud, Universidad Juárez Autónoma de Tabasco, \\ Villahermosa 86100, Tabasco, Mexico; jblecastillo@hotmail.com (J.L.B.-C.); \\ antony-jano@hotmail.com (A.P.-M.); crystell_guzman@hotmail.com (C.G.-P.) \\ 4 Hospital General de Yajalón, Secretaría de Salud, Yajalón 29930, Chiapas, Mexico; \\ dralilialonar@yahoo.com.mx \\ 5 Subdirección de Investigaciones Clínicas, Instituto Nacional de Psiquiatría Ramón de la Fuente Muñiz, \\ Ciudad de México 14370, Mexico; fresan@imp.edu.mx \\ * Correspondence: alfonso_tovillaz@yahoo.com.mx (C.A.T.-Z.); iselajuarezrojop@hotmail.com (I.E.J.-R.); \\ Tel.: +52-993-358-1500 (C.A.T.-Z.); +52-993-358-6900 (I.E.J.-R.)
}

Received: 17 August 2018; Accepted: 21 September 2018; Published: 25 September 2018

\begin{abstract}
It is estimated that almost 366 million people are currently suffering from diabetes mellitus worldwide. However, it has been suggested that coffee consumption has a protective effect against the development of type 2 diabetes mellitus. This association has been observed in many regions around the world. Today, there are no reports in Mexico regarding this association. Therefore, the aim of this study was to assess the association between coffee intake and self-reported type 2 diabetes mellitus in the southeastern part of Mexico. This study included 1277 residents of Comalcalco, a municipality of Tabasco State, Mexico. We calculated the prevalence for diabetes and performed multivariate analysis using multiple logistic regressions to evaluate the combined association with type 2 diabetes mellitus. The prevalence of the diabetes was $12.52 \%$ (95\% CI: 10.67-14.38). The majority of people surveyed (77.29\%; 95\% CI: 74.95-79.60) indicated they were coffee drinkers. The results of multivariate analysis showed a non-significant relationship between the number of cups of coffee drank and type 2 diabetes mellitus. The adjusted odds ratio gave the following values: 1.20 , (95\% CI: 0.59-2.41) for non-daily consumption; 1.66 (0.82-3.34), for 1 cup of coffee peer day, and $1.49(0.78-2.86)$ for 2-3 cups. Subsequently, an adjustment was made for age, gender, marital status, education, alcohol consumption, and cigarette smoking. In our population, we did not observe an association between coffee intake and its protective relationship with self-reported type 2 diabetes mellitus.
\end{abstract}

Keywords: diabetes; coffee; Mexican population 


\section{Introduction}

The global prevalence of diabetes mellitus is continuously rising. Nowadays, almost 366 million people worldwide have diabetes mellitus; it is estimated that by 2030 diabetes mellitus will affect 552 million people [1]. In Mexico, the prevalence of this disease is on the rise. In 1993, the prevalence of diabetes mellitus was $4.6 \%$; in 2007 , it increased to $7.30 \%$; in $2012,9.17 \%$ of the general population had the disease [2-4].

Coffee is the most consumed beverage in the world. It is a complex mixture of thousands of compounds including caffeine, phenolic compounds, niacin, minerals, and fiber [5]. With regard to diabetes, the literature suggests that sub-clinical inflammation has been implicated in the development of insulin resistance and coffee consumption may improve insulin sensitivity by decreasing inflammation [6-8] (for a more detailed description of the mechanism, see [5,9]). Recently, many studies have encountered a protective association between coffee consumption and type 2 diabetes mellitus [6,10-14]. This protective effect has been observed in different countries and populations such as African American women [10], populations of California, Florida, Louisiana, New Jersey, North Carolina, and Pennsylvania [15], and other states of the American Union [12], as well as the Taiwan-Chinese population [11], the Brazilian population [16], the Singapore-Chinese population [17], the Malay-Chinese and Indian populations [6], and other population samples [18-20]. Moreover, a first meta-analysis reported that habitual coffee consumption was associated with a substantial lower risk for type 2 diabetes [21]. Similarly, in a second meta-analysis, high intake of coffee was associated with a reduced risk for diabetes [22,23]. However, at the present time, there are no reports in the Mexican population evaluating the association between coffee consumption and diabetes mellitus. The consumption of coffee per capita in Mexico is $1.41 \mathrm{~kg}$ every year [24]. This consumption is much lower than that reported for developing countries [25]. Additionally, Mexico is among the countries with major prevalence of diabetes mellitus [26]. Thus, it is important know the association between coffee consumption and prevalence of self-reported type 2 diabetes in the Mexican population, particularly when designing programs to prevent or treat diabetes mellitus in the Mexican population. We performed a cross-sectional association study to assess the possible protective effect of coffee intake against type 2 diabetes mellitus in a population of Southeastern Mexico who self-reported having diabetes.

\section{Materials and Methods}

\subsection{Participants}

We designed a cross-sectional population-based survey for individuals living in Comalcalco. Comalcalco is a municipality of Tabasco with 41,458 inhabitants, which represented $21.5 \%$ of the overall population of Tabasco State at the moment of the study. The inclusion criteria were individuals 18-79 years of age and residents of the Comalcalco municipality. The exclusion criteria were individuals who did not complete the interview, and individuals who did not sign the informed consent. In a simple random sampling, a total of 1400 people were surveyed. However, only 1277 people completed the inclusion criteria and were enrolled in this study.

\subsection{Ethics Statement}

We only surveyed individuals descending from Mexican parents. The retrieved data were confidential. Before the interview, participants were informed about the aims of the study and signed a declaration of informed consent. This study was conducted according to the guidelines laid down in the Declaration of Helsinki. This study was approved by the DAMC-UJAT Ethics and Research Committee (UJAT-DAMC-2012-03), as well as by the ethics committee of the Ministry of Health of Tabasco (INV/262/C/0512). 


\subsection{Data Collection}

We designed a cross-sectional population-based survey and a questionnaire to obtain information regarding different habits and health conditions between healthy individuals and people with type 2 diabetes. A semi-structured questionnaire was designed specifically for this study, which was used to collect detailed data of sociodemographic characteristic (gender, age, socio-behavioral aspects, years of schooling), health habits (cigarette smoking and alcohol intake), and coffee consumption (Cronbach's alpha 0.69). The frequency of coffee intake ranged from none to six cups or more per day. However, the number of participants who drank more than 5 cups per day was small; therefore; we decided to change the category of 4-6 cups per day into $\geq 4$ cups per day ( 4 cups, $n=9,5$ cups, $n=36,6$ cups, $n=7$ ). For the analysis, we combined two types of coffee consumption: instant and filtered. Participants were interviewed by nurses and medical students. The questionnaire was applied in person. For sample calculation, we used an a priori model, $\alpha=0.05$, and $70 \%$ prevalence for coffee intake was considered. Precision of $2.0 \%$ was adopted. Sample size $=1188$, with a power of 0.95 .

\subsection{Anthropometric Measurements}

The following parameters were collected: height, weight, and blood pressure. These measurements were collected as previously reported [27].

\subsection{Definition of Type 2 Diabetes}

Self-reported diagnoses of diabetes were rendered by the participants. During the assessment of self-reported diagnosis, the time of onset of diabetes (in years) was obtained. In addition, a supplementary questionnaire regarding symptoms was applied to confirm the diagnosis of this illness. Glucose levels in plasma were not measured.

\subsection{Definition of Use of Substances}

History of alcohol consumption per week was asked. The person with regular weekend use or sporadic use of alcoholic beverages was considered an alcohol consumer. Individuals who smoke at least 10 cigarettes per week were classified as smokers. Carbon monoxide in breath was not measured. People consuming alcoholic beverages or cigarettes were considered users of substances.

\subsection{Statistical Analysis}

Descriptive statistics was used to characterize the sample using frequencies and percentages for categorical variables and mean \pm standard deviations for continuous variables. The KolmogorovSmirnov test was used to analyze whether the continuous variables were under normal distribution. The Kolmogorov-Smirnov test showed $p$-values $\geq 0.20$ ). Dummy codification was used for continuous variables to perform comparative analyses using chi-square tests and obtain estimated odd ratios (95\% CI) for individual variables in association with diabetes. Age was categorized using a cutoff value of up to 50 as previously reported [27]. For level of education, six years of elementary school was the value to categorize the sample as this level of education is considered the minimum to have in Mexico. BMI was dichotomized in normal and overweight/obesity in accordance with international obesity task force criteria, and systolic and diastolic BP values were categorized according to Mexican official norm NOM-030-SSA2-1999. Subsequently, multivariate analysis using multiple logistic regressions was performed to evaluate the combined relationship of several factors associated with diabetes among the overall population after adjusting for confounding variables (in this analysis we included socio-demographic, anthropometric, and clinic characteristics as explanatory variables). Results are presented as adjusted odds ratios (AOR) with 95\% CI, which express the magnitude of the relationship of each category on the outcome relative to the reference category. Prevalence was calculated using EPIDAT 3.1 software (software for epidemiologic analysis of tabulated data, v. 3.1). Other calculations 
were performed with the SPSS version 14.0 software (SPSS Inc., Chicago, IL, USA). The level of significance was set at $p=0.05$.

\section{Results}

\subsection{Descriptive Characteristics}

The socio-demographic characteristics of the participants are summarized in Table 1 . The larger number of participants were females (53.20\%); of these, $54.0 \%$ were married and $36.20 \%$ were single. The main occupations were classified as part-time job (41.00\%) and housewife (29.00\%). The mean age was $37.27 \pm 13.44$ years old with a range of $18-79$. The mean level of education was $5.01 \pm 4.63$ years, with a range of 0-21 years of school education. The mean body mass index was $27.92 \pm 4.31$ (range 20-45.87). The mean systolic BP was 116.28 \pm 11.12 (range 70-170) and the mean diastolic BP was $78.22 \pm 9.78$ (Table 1). Significant differences emerged between groups in terms marital status, occupation, age, education, and body mass index (Table 1). Patients with diabetes mellitus were predominantly married. They worked full time and had a higher body mass index.

Table 1. Association between socio-demographic and clinical characteristics divided by type 2 diabetes of the populations in the study.

\begin{tabular}{|c|c|c|c|c|c|c|}
\hline \multicolumn{2}{|c|}{ Characteristics } & \multirow{3}{*}{$\begin{array}{c}\begin{array}{c}\text { All Sample } \\
\boldsymbol{n}(\boldsymbol{\%})\end{array} \\
597(46.80) \\
680(53.20)\end{array}$} & \multirow{3}{*}{$\begin{array}{c}\begin{array}{c}\text { With } \\
\text { Diabetes }\end{array} \\
69(43.10) \\
91(56.90)\end{array}$} & \multirow{3}{*}{$\begin{array}{c}\begin{array}{c}\text { Without } \\
\text { Diabetes }\end{array} \\
528(47.30) \\
589(52.70)\end{array}$} & \multirow{3}{*}{$\begin{array}{c}\text { OR }(\mathbf{9 5} \% \mathrm{CI}) \\
0.84 \\
(0.60-1.18)\end{array}$} & \multirow{3}{*}{$\begin{array}{c}p \text {-Value } \\
0.32\end{array}$} \\
\hline \multirow[t]{2}{*}{ Gender } & Male & & & & & \\
\hline & Female & & & & & \\
\hline \multirow[t]{3}{*}{ Marital Status } & Married & $690(54.00)$ & $100(62.50)$ & $590(52.80)$ & & $<0.01$ \\
\hline & Single & $463(36.20)$ & $37(23.10)$ & $426(38.10)$ & & \\
\hline & Separated/divorced & $57(4.50)$ & $13(8.10)$ & $44(3.90)$ & & \\
\hline \multirow[t]{5}{*}{ Occupation } & Unemployed & $38(3.00)$ & $5(3.10)$ & $33(3.00)$ & & $<0.001$ \\
\hline & Housewife & $370(29.00)$ & $47(29.70)$ & $323(28.90)$ & & \\
\hline & Student & $70(5.50)$ & $3(1.90)$ & $67(6.00)$ & & \\
\hline & Half-time job & $524(41.00)$ & $29(18.10)$ & $495(44.30)$ & & \\
\hline & Full-time job & $275(21.50)$ & $76(47.50)$ & $199(17.80)$ & & \\
\hline \multirow[t]{2}{*}{ Education } & $\begin{array}{c}\text { Up to } 6 \text { years of } \\
\text { schooling }\end{array}$ & $807(63.20)$ & $84(52.50)$ & $723(64.70)$ & $\begin{array}{c}0.60 \\
(0.43-0.84)\end{array}$ & $<0.01$ \\
\hline & $>6$ years of schooling & $470(36.80)$ & $76(47.50)$ & $394(35.30)$ & & \\
\hline \multirow[t]{2}{*}{ Body mass index } & Up to 25 & $460(36.00)$ & $38(23.80)$ & $422(37.80)$ & $\begin{array}{c}0.51 \\
(0.34-0.75)\end{array}$ & $<0.001$ \\
\hline & $>25$ & $817(64.00)$ & $122(76.30)$ & $695(62.20)$ & & \\
\hline \multirow[t]{2}{*}{ Use of substances } & Yes & 397 (31.10) & $59(36.90)$ & $338(30.30)$ & $\begin{array}{c}1.34 \\
(0.95-1.90)\end{array}$ & 0.09 \\
\hline & No & $880(68.90)$ & $101(63.10)$ & $779(69.70)$ & & \\
\hline Systolic BP (mmHg) & Up to 120 & $1073(84.00)$ & $126(78.80)$ & $947(84.80)$ & $\begin{array}{c}0.66 \\
(0.44-1.00)\end{array}$ & 0.05 \\
\hline
\end{tabular}

significance in bold.

\subsection{Prevalence of Type 2 Diabetes and Obesity}

In the overall population, $12.52 \%$ (95\% CI: 10.67-14.38) were positive for diabetes. The prevalence of type 2 diabetes was $15.52 \%$ (95\% CI 12.26-18.80) in males and $12.90 \%$ (95\% CI: 10.17-15.64) in females. 


\subsection{Coffee Consumption}

In our sample, from the 1277 participants, $77.29 \%$ (95\% CI: 74.95-79.60) were coffee drinkers.

Table 2 summarizes the results of univariate and multivariate analyses for the relationship between the number of cups of coffee per day and the presence of diabetes. No relation between coffee consumption and type 2 diabetes was observed. When compared with the daily consumption of 4 or more cups of coffee, we found the following adjusted odd ratio (AOR) values: 1.20 (95\% CI 0.59-2.41) for non-daily consumption, $1.66(0.82-3.34)$ for 1 cup daily consumption, and $1.49(0.78-2.86)$ for to 2-3 cups.

Table 2. Relationship between coffee consumption and prevalence of diabetes after adjustment for potential confounding factors.

\begin{tabular}{cccccc}
\hline $\begin{array}{c}\text { Coffee } \\
\text { Consumption }\end{array}$ & $\begin{array}{c}\text { No. of People } \\
\boldsymbol{n = 1 2 7 7}\end{array}$ & $\begin{array}{c}\text { Prevalence of } \\
\text { Diabetes } \boldsymbol{n} \mathbf{( \% )}\end{array}$ & $\begin{array}{c}\text { Without } \\
\text { Diabetes } \boldsymbol{n} \mathbf{( \% )}\end{array}$ & OR (95\% CI) & $\begin{array}{c}\text { Multivariate OR } \\
\mathbf{( 9 5 \% ~ C I ) , ~} \boldsymbol{p} \text { Value * }\end{array}$ \\
\hline Nondaily & $290(22.70)$ & $36(12.40)$ & $254(87.60)$ & $1.31(0.67-2.57)$ & $1.20(0.59-2.41), 0.60$ \\
1 cup/d & $248(19.40)$ & $38(15.30)$ & $210(84.70)$ & $1.68(0.86-3.28)$ & $1.66(0.82-3.34), 0.15$ \\
$2-3$ cups/d & $605(47.40)$ & $73(12.10)$ & $532(87.90)$ & $1.27(0.68-2.37)$ & $1.49(0.78-2.86), 0.22$ \\
$\geq 4$ cups/d & $134(10.50)$ & $13(9.70)$ & $121(90.30)$ & Reference & Reference \\
\hline
\end{tabular}

* Adjusted OR for age, body mass index, gender, marital status, education, systolic BP, diastolic BP, alcohol consumption, and smoking habit.

\section{Discussion}

From 2000 to 2007, 477,036 individuals died of diabetes mellitus in Mexico [28]. Diabetes mellitus was the second cause of death claiming $9.7 \%$ of total deaths [29]. The mortality rate increased from 77.9 in 2000 to 89.2 in 2007 per 100,000 inhabitants [28]. In consequence, we estimated the prevalence of type 2 diabetes mellitus in our population and analyzed the prevalence of coffee consumption for a possible association between coffee intake and a Tabascan population who self-reported type 2 diabetes mellitus. To our knowledge, this is the first study evaluating this association in the Mexican population. The present study failed to detect any association between coffee consumption and a decrease of self-reported type 2 diabetes mellitus.

In the population studied, we found a diabetes mellitus prevalence of $12.52 \%$. Although it is considered high, it was an expected result, because the National Survey of Healthy and Nutrition 2012 showed that the prevalence of diabetes mellitus in Tabasco State is higher $(9.4 \%)$ than the national average (9.2\%) [30]. Many factors could be associated to this high prevalence i.e., the diet of the local population [31]. In recent years, coffee intake has been associated with a lower risk for type 2 diabetes in several studies [12,19,32-34]. This has been observed in caffeinated and decaffeinated coffee [35]. However, in our study, we did not encounter evidence for an association between coffee consumption and self-reported type 2 diabetes. There is only one other study that has reported this lack of association [36]. It is likely that the geographic localization of the sample where the study was performed and the tribal customs related to coffee consumption may have contributed to this lack of association [37].

There are a number of possible reasons for the lack of association between coffee consumption and the protective association with type 2 diabetes mellitus that we considered. First, the number of participants in our study may not be large enough to show a difference between the coffee consumption and the presence of self-reported type 2 diabetes. Second, alcohol and cigarette smoking were a covariate that influenced our results, since the prevalence of substance use in our sample was $31 \%$, which is higher than what has been reported in other Mexican populations [38]. Other possible explanation may be that the inverse association between coffee consumption and diabetes was observed only in a specific age group. For example, in our study, the mean age was $37.27 \pm 13.44$ years old, and studies in other populations included older patients: 50-70 years of age [15], 40-60 years old [11,39], and $45-75$ years of age [34,37]. Another possibility may be the small consumption of coffee in our population. The average coffee consumption in the Mexican population is only $161 \mathrm{~mL}$ per day in 
individuals 19 years old and older [40,41]. This amount is lower than the standard coffee cup serving size of $240 \mathrm{~mL}$. However, the inverse association between coffee consumption and diabetes has been observed in China, which is a country with a coffee consumption rate similar to that of Mexico [11]. Interestingly, a non-protective effect of coffee consumption in type 2 diabetes has been observed in studies that evaluated the association between coffee consumption and coronary heart disease in a Mexican population [42].

As a limitation of our study, glucose levels were not quantified to confirm the diagnosis of diabetes mellitus. Second, we did not utilize a questionnaire to evaluate food intake and physical activity. Third, in North America and the Caribbean, it has been estimated that $29.2 \%$ of the population have been undiagnosed with diabetes mellitus [1], and this can lead to outcome misclassification and attenuation of risk estimates. Fourth, people who drank decaffeinated coffee were not evaluated. Future studies are needed to explore the role of decaffeinated coffee and type 2 diabetes mellitus in our population. Fifth, the long-term relationship between coffee consumption and type 2 diabetes mellitus prevention in older individuals was not evaluated. Our results should not be generalized for the entire Mexican population, as only individuals of one city were evaluated. The most important limitation of the present study is its cross-sectional design. Even though our results showed no association between coffee intake and diabetes, future longitudinal studies, specifically a cohort study, may give clearer results about this lack of association or even show that there can be an association that is evidenced with the passage of time.

\section{Conclusions}

In conclusion, our results yielded a lack of association between coffee intake and self-reported type 2 diabetes in a population of Southeastern Mexico. However, low coffee consumption in our population, sample size, average age, and methodological differences with other studies contributed to the lack of association, and future studies that overcome these limitations should be carried out.

Author Contributions: Conceptualization, I.E.J.-R. and C.A.T.-Z.; Methodology, A.K.G.-M.; Software, T.B.G.-C.; Formal Analysis, C.A.T.-Z. and D.G.A.-V.; Investigation, T.G.G.-P.; Resources, I.E.J.-R.; Writing-Original Draft Preparation, M.L.L.-N.; Writing-Review \& Editing, E.C.-D. and A.F.; Visualization, J.L.B.-C.; Supervision, A.P.-M.; Funding Acquisition, C.G.-P.

Funding: This research was funded by Universidad Juárez Autónoma de Tabasco grant number UJAT-IB-2105-05.

Acknowledgments: Data collection of the subjects were performed with the support of a grant from Universidad Juárez Autónoma de Tabasco (UJAT-IB-2105-05).

Conflicts of Interest: The authors declare no conflict of interest.

\section{References}

1. Federation, I.D. Idf Diabetes Atlas, 5th ed.; International Diabetes Federation: Brussels, Belgium, 2011.

2. Olaiz, G.; Rivera, J.; Shamah, T.; Rojas, R.; Villalpando, S.; Hernández, M.; Sepúlveda, J. Encuesta Nacional de Salud y Nutrición 2006; Instituto Nacional de Salud Pública: Cuernavaca, Mexico, 2006.

3. Barquera, S.; Campos-Nonato, I.; Aguilar-Salinas, C.; Lopez-Ridaura, R.; Arredondo, A.; Rivera-Dommarco, J. Diabetes in Mexico: Cost and management of diabetes and its complications and challenges for health policy. Glob. Health 2013, 9, 3. [CrossRef] [PubMed]

4. Hernández-Ávila, M.; Gutiérrez, J.P.; Reynoso-Noverón, N. Diabetes mellitus en México. El estado de la epidemia. Salud Publica de Mexico 2013, 55, s129-s136. [CrossRef] [PubMed]

5. Natella, F.; Scaccini, C. Role of coffee in modulation of diabetes risk. Nutr. Rev. 2012, 70, 207-217. [CrossRef] [PubMed]

6. Rebello, S.A.; Chen, C.H.; Naidoo, N.; Xu, W.; Lee, J.; Chia, K.S.; Tai, E.S.; van Dam, R.M. Coffee and tea consumption in relation to inflammation and basal glucose metabolism in a multi-ethnic Asian population: A cross-sectional study. Nutr. J. 2011, 10, 1475-2891. [CrossRef] [PubMed] 
7. Kempf, K.; Herder, C.; Erlund, I.; Kolb, H.; Martin, S.; Carstensen, M.; Koenig, W.; Sundvall, J.; Bidel, S.; Kuha, S.; et al. Effects of coffee consumption on subclinical inflammation and other risk factors for type 2 diabetes: A clinical trial. Am. J. Clin. Nutr. 2010, 91, 950-957. [CrossRef] [PubMed]

8. Wang, H.; Jeong, H.; Kim, N.H.; Kang, Y.; Hwang, K.; Lee, H.; Hong, J.H.; Oh, K.S. Association between beverage intake and obesity in children: The Korea National Health and Nutrition Examination Survey (KNHANES) 2013-2015. Nutr. Res. Pract. 2018, 12, 307-314. [CrossRef] [PubMed]

9. Pimentel, G.D.; Zemdegs, J.C.; Theodoro, J.A.; Mota, J.F. Does long-term coffee intake reduce type 2 diabetes mellitus risk? Diabetol. Metab. Syndr. 2009, 1, 6. [CrossRef] [PubMed]

10. Boggs, D.A.; Rosenberg, L.; Ruiz-Narvaez, E.A.; Palmer, J.R. Coffee, tea, and alcohol intake in relation to risk of type 2 diabetes in African American women. Am. J. Clin. Nutr. 2010, 92, 960-966. [CrossRef] [PubMed]

11. Lin, W.Y.; Xaiver Pi-Sunyer, F.; Chen, C.C.; Davidson, L.E.; Liu, C.S.; Li, T.C.; Wu, M.F.; Li, C.I.; Chen, W.; Lin, C.C. Coffee consumption is inversely associated with type 2 diabetes in Chinese. Eur. J. Clin. Investig. 2011, 41, 659-666. [CrossRef] [PubMed]

12. Bhupathiraju, S.N.; Pan, A.; Malik, V.S.; Manson, J.E.; Willett, W.C.; van Dam, R.M.; Hu, F.B. Caffeinated and caffeine-free beverages and risk of type 2 diabetes. Am. J. Clin. Nutr. 2013, 97, 155-166. [CrossRef] [PubMed]

13. Ohnaka, K.; Ikeda, M.; Maki, T.; Okada, T.; Shimazoe, T.; Adachi, M.; Nomura, M.; Takayanagi, R.; Kono, S. Effects of 16-week consumption of caffeinated and decaffeinated instant coffee on glucose metabolism in a randomized controlled trial. J. Nutr. Metab. 2012, 2012, 207426. [CrossRef] [PubMed]

14. Ericson, U.; Hindy, G.; Drake, I.; Schulz, C.A.; Brunkwall, L.; Hellstrand, S.; Almgren, P.; Orho-Melander, M. Dietary and genetic risk scores and incidence of type 2 diabetes. Genes Nutr. 2018, 13, 13. [CrossRef] [PubMed]

15. Freedman, N.D.; Park, Y.; Abnet, C.C.; Hollenbeck, A.R.; Sinha, R. Association of coffee drinking with total and cause-specific mortality. N. Engl. J. Med. 2012, 366, 1891-1904. [CrossRef] [PubMed]

16. Machado, L.M.; da Costa, T.H.; da Silva, E.F.; Dorea, J.G. Association of moderate coffee intake with self-reported diabetes among urban Brazilians. Int. J. Environ. Res. Public Health 2011, 8, 3216-3231. [CrossRef] [PubMed]

17. Odegaard, A.O.; Pereira, M.A.; Koh, W.P.; Arakawa, K.; Lee, H.P.; Yu, M.C. Coffee, tea, and incident type 2 diabetes: The singapore chinese health study. Am. J. Clin. Nutr. 2008, 88, 979-985. [CrossRef] [PubMed]

18. Pereira, M.A.; Parker, E.D.; Folsom, A.R. Coffee consumption and risk of type 2 diabetes mellitus: An 11-year prospective study of 28,812 postmenopausal women. Arch. Intern. Med. 2006, 166, 1311-1316. [CrossRef] [PubMed]

19. Van Dam, R.M.; Feskens, E.J. Coffee consumption and risk of type 2 diabetes mellitus. Lancet 2002, 360, 1477-1478. [CrossRef]

20. Torres-Collado, L.; García-de la Hera, M.; Navarrete-Muñoz, E.; Compañ-Gabucio, L.; Gonzalez-Palacios, S.; Vioque, J. Coffee drinking and associated factors in an elderly population in Spain. Int. J. Environ. Res. Public Health 2018, 15, 1661. [CrossRef] [PubMed]

21. van Dam, R.M.; Hu, F.B. Coffee consumption and risk of type 2 diabetes: A systematic review. JAMA 2005, 294, 97-104. [CrossRef] [PubMed]

22. Huxley, R.; Lee, C.M.; Barzi, F.; Timmermeister, L.; Czernichow, S.; Perkovic, V.; Grobbee, D.E.; Batty, D.; Woodward, M. Coffee, decaffeinated coffee, and tea consumption in relation to incident type 2 diabetes mellitus: A systematic review with meta-analysis. Arch. Intern. Med. 2009, 169, 2053-2063. [CrossRef] [PubMed]

23. Carlstrom, M.; Larsson, S.C. Coffee consumption and reduced risk of developing type 2 diabetes: A systematic review with meta-analysis. Nutr. Rev. 2018, 76, 395-417. [CrossRef] [PubMed]

24. Aceves-Navarro, L.A.; Rivera-Hernández, B.; López-Castañeda, A.; Palma-López, D.J.; GonzálezMancillas, R.; Juárez-López, J.F. Potential areas and vulnerability of the robust coffee crop (Coffea canephora P.) to climate change in the state of tabasco, Mexico. Nova Sci. 2018, 10, 369-396. [CrossRef]

25. Chamorro, A.C.A.; Benavides, N.A.B. El mercado del café en los contextos mundial, nacional y regional. Rev. UNIMAR 2018, 35, 325-348.

26. Rojas-Martínez, R.; Basto-Abreu, A.; Aguilar-Salinas, C.A.; Zárate-Rojas, E.; Villalpando, S.; BarrientosGutiérrez, T. Prevalence of previously diagnosed diabetes mellitus in Mexico. Salud Publica de Mexico 2018, 60, 224-232. [CrossRef] [PubMed] 
27. Tovilla-Zarate, C.; Juarez-Rojop, I.; Peralta Jimenez, Y.; Jimenez, M.A.; Vazquez, S.; Bermudez-Ocana, D.; Ramon-Frias, T.; Genis Mendoza, A.D.; Garcia, S.P.; Narvaez, L.L. Prevalence of anxiety and depression among outpatients with type 2 diabetes in the Mexican population. PLoS ONE 2012, 7, e36887. [CrossRef] [PubMed]

28. Sanchez-Barriga, J.J. Mortality trends from diabetes mellitus in the seven socioeconomic regions of Mexico, 2000-2007. Rev. Panam. Salud Publ. 2010, 28, 368-375. [CrossRef] [PubMed]

29. Stevens, G.; Dias, R.H.; Thomas, K.J.A.; Rivera, J.A.; Carvalho, N.; Barquera, S.; Hill, K.; Ezzati, M. Characterizing the epidemiological transition in Mexico: National and subnational burden of diseases, injuries, and risk factors. PLoS Med. 2008, 5, e125.

30. Encuesta Nacional de Salud y Nutrición 2012. Resultados Por Entidad Federativa, Tabasco; Instituto Nacional de Salud Pública: Cuernavaca, Mexico, 2013.

31. Navarrete-Cortes, A.; Ble-Castillo, J.L.; Guerrero-Romero, F.; Cordova-Uscanga, R.; Juarez-Rojop, I.E.; Aguilar-Mariscal, H.; Tovilla-Zarate, C.A.; Lopez-Guevara Mdel, R. No effect of magnesium supplementation on metabolic control and insulin sensitivity in type 2 diabetic patients with normomagnesemia. Magnes. Res. Off. Organ Int. Soc. Dev. Res. Magnes. 2014, 27, 48-56.

32. Salazar-Martinez, E.; Willett, W.C.; Ascherio, A.; Manson, J.E.; Leitzmann, M.F.; Stampfer, M.J.; Hu, F.B. Coffee consumption and risk for type 2 diabetes mellitus. Ann. Intern. Med. 2004, 140, 1-8. [CrossRef] [PubMed]

33. van Dam, R.M.; Willett, W.C.; Manson, J.E.; Hu, F.B. Coffee, caffeine, and risk of type 2 diabetes: A prospective cohort study in younger and middle-aged U.S. Women. Diabetes Care 2006, 29, 398-403. [CrossRef] [PubMed]

34. Doo, T.; Morimoto, Y.; Steinbrecher, A.; Kolonel, L.N.; Maskarinec, G. Coffee intake and risk of type 2 diabetes: The multiethnic cohort. Public Health Nutr. 2013, 27, 1-9. [CrossRef] [PubMed]

35. Ding, M.; Bhupathiraju, S.N.; Chen, M.; van Dam, R.M.; Hu, F.B. Caffeinated and decaffeinated coffee consumption and risk of type 2 diabetes: A systematic review and a dose-response meta-analysis. Diabetes Care 2014, 37, 569-586. [CrossRef] [PubMed]

36. Saremi, A.; Tulloch-Reid, M.; Knowler, W.C. Coffee consumption and the incidence of type 2 diabetes. Diabetes Care 2003, 26, 2211-2212. [CrossRef] [PubMed]

37. Zhang, Y.; Lee, E.T.; Cowan, L.D.; Fabsitz, R.R.; Howard, B.V. Coffee consumption and the incidence of type 2 diabetes in men and women with normal glucose tolerance: The strong heart study. Nutr. Metab. Cardiovasc. Dis. 2011, 21, 418-423. [CrossRef] [PubMed]

38. Lee, J.H.; Oh, M.K.; Lim, J.T.; Kim, H.G.; Lee, W.J. Effect of coffee consumption on the progression of type 2 diabetes mellitus among prediabetic individuals. Korean J. Fam. Med. 2016, 37, 7-13. [CrossRef] [PubMed]

39. Lin, C.C.; Liu, C.S.; Lai, M.M.; Li, C.I.; Chen, C.C.; Chang, P.C.; Lin, W.Y.; Lee, Y.D.; Lin, T.; Li, T.C. Metabolic syndrome in a taiwanese metropolitan adult population. BMC Public Health 2007, 7, 239. [CrossRef] [PubMed]

40. Current Worlwide Annual Coffee Consumption per Capita. Available online: http://chartsbin.com/view/ 581 (accessed on 21 February 2011).

41. Rivera, J.A.; Munoz-Hernandez, O.; Rosas-Peralta, M.; Aguilar-Salinas, C.A.; Popkin, B.M.; Willett, W.C. Beverage consumption for a healthy life: Recommendations for the mexican population. Salud Publica de Mexico 2008, 50, 173-195. [CrossRef] [PubMed]

42. MacKenzie, G.; Greig, M.; Hay, I.; Pemberton, J. Competing risk analysis of factors related to long-term incidence of chd. J. Epidemiol. Commun. Health 2017, 71, 33-36. [CrossRef] [PubMed]

(C) 2018 by the authors. Licensee MDPI, Basel, Switzerland. This article is an open access article distributed under the terms and conditions of the Creative Commons Attribution (CC BY) license (http://creativecommons.org/licenses/by/4.0/). 